\title{
PSITTACUS PULLARIUS.
}

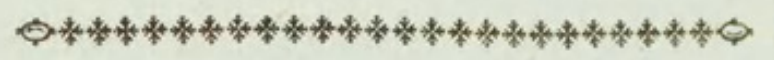

CHARACTER GENERICUS.

Roftrum aduncum: mandibula fuperiore mobili, cera inftructa.

Nares in roftri bafi.

Lingua carnofa, obtufa, integra.

Pedes fcanforii.

$$
\text { Lin. Syf. Nat. p. } 139 .
$$

CHARACTER SPECIFICUS,

PSITTACUS brachyurus viridis, fronte rubra, cauda fulva fafcia nigra, orbitis cinereis.

Lin. Syft. Nat. p. 149.

\section{PSITTACUS GUINEENSIS.}

Edw. Av. t. 237. f. 1.

Lath. Synops. 1. p. 309.

In caveis inclufam hanc aviculam plerique tam frequenter confpexerunt, ut hoc ipfum ab admiratione detrahat quam aliter fibi vindicaret excellens pulchritudo. Hiftoriæ naturalis cultoribus tam probe cognita eft hæc fpecies, ut illam peculiariter defcribere non fit neceffe: fatis fit dicere fpeciem effe pulcherrimam; moresque ejus fuaves et manfuetos formæ tam 
eximiæ bene refpondere. Africæ eft indigena, et in Guinea frequentiffima eft. In India etiam Orientali invenitur. Nomen ejus Anglicanum commune eft Guinea-Sparrow. 



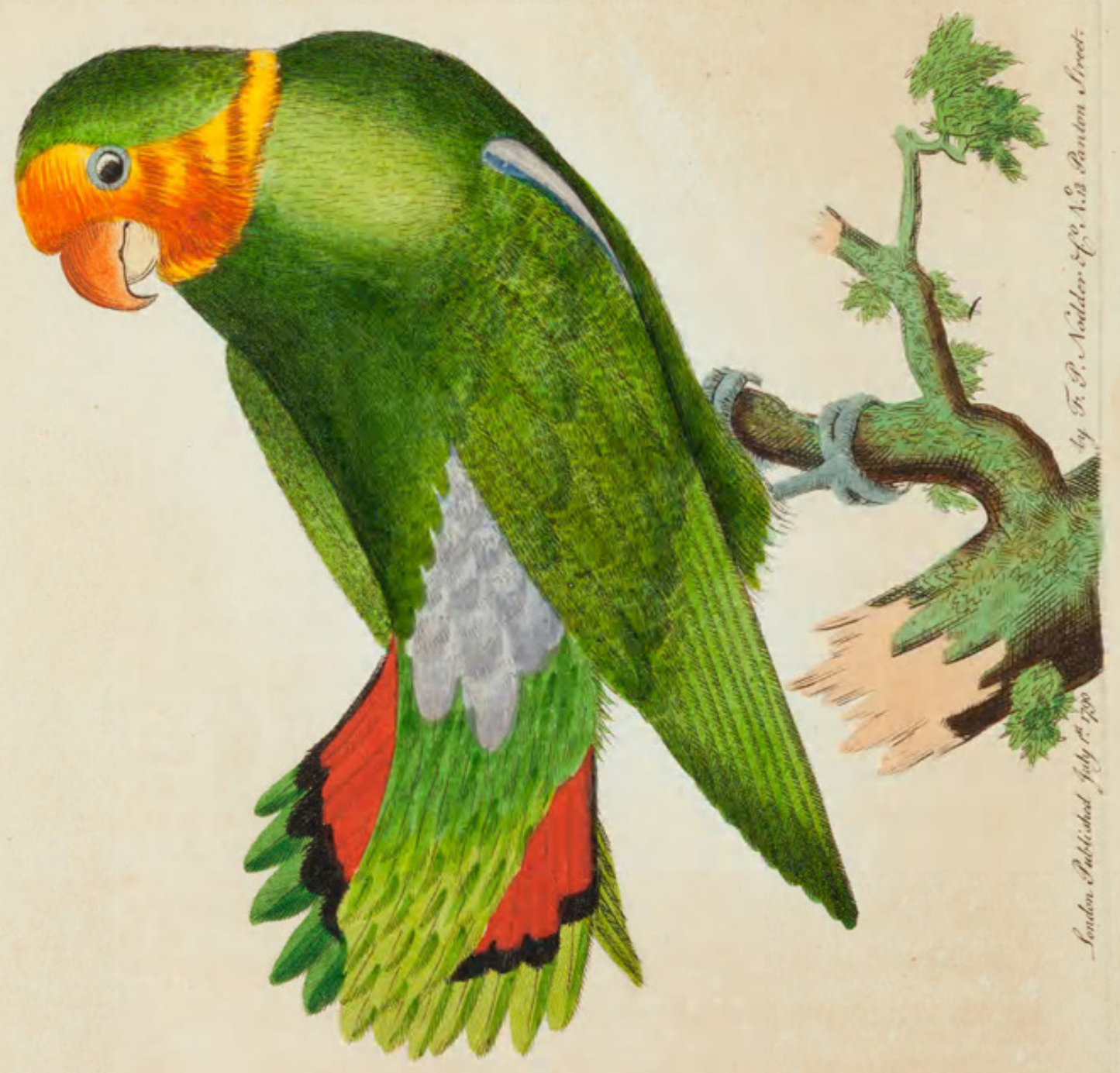




\section{GUINEA PARRAKEET.}

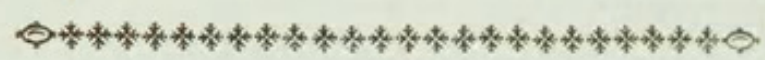

\section{GENERIC CHARACTER.}

Bill hooked. Upper mandible moveable. Nofrils round, placed in the bafe of the bill. Tongue flefhy, broad, blunt at the end.

Legs fhort. Toes formed for climbing, viz. two backward and two forward.

Linnaus and Pennant.

\section{SPECIFIC CHARACTER, छC.}

SHORT-TAILED GREEN PARROT, with red front; tail fulvous with a black bar; orbits of the eyes grey.

Lin.

\section{RED-HEADED GUINEA PARRAKEET.}

\section{Latbam, fol. 1. p. 309.}

This beautiful little bird is fo often feen in cages, that the circumftance of its not being a rare fpecies feems in fome degree to leffen the admiration due to its uncommon elegance. As it is fo well known to Naturalifts, it is unneceffary to fay more than that it is one of the moft brilliant of its genus, and that the beauty of its appearance is equalled by the gentlenefs $\mathrm{P}_{2}$ 
of its manners. It is an African bird, and abounds in Guinea. It is alfo found in the Eaft Indies. In England this bird is generally called by the name of the Guinea-Sparrow. 


\section{$2 \mathrm{BHL}$ Biodiversity Heritage Library}

Shaw, George. 1790. "The Guinea Parrakeet, Psittacus pullarius [PI. 35]." The Naturalist's Miscellany 1(XII), https://doi.org/10.5962/p.310687.

View This Item Online: https://www.biodiversitylibrary.org/item/281460

DOI: https://doi.org/10.5962/p.310687

Permalink: https://www.biodiversitylibrary.org/partpdf/310687

\section{Holding Institution}

Museums Victoria

\section{Sponsored by}

Atlas of Living Australia

\section{Copyright \& Reuse}

Copyright Status: Public domain. The BHL considers that this work is no longer under copyright protection.

This document was created from content at the Biodiversity Heritage Library, the world's largest open access digital library for biodiversity literature and archives. Visit BHL at https://www.biodiversitylibrary.org. 